\title{
Health Risk Assessment of Heavy Metals in Prawn Penaeus merguiensis Collected in 2007 from Sri Serdang Market, Peninsular Malaysia
}

\section{Chee Kong Yap ${ }^{1 *}$, Wan Hee Cheng ${ }^{2}$, Mohd Hafetz Ali ${ }^{1}$, Rosimah Nulit ${ }^{1}$, Shih Hao Tony Peng ${ }^{3}$, Mohamad Saupi Ismail $^{4}$, and Chee Seng Leow ${ }^{5}$}

${ }^{1}$ Department of Biology, Faculty of Science, Universiti Putra Malaysia, Selangor, Malaysia

${ }^{2}$ Inti International University, Persiaran Perdana BBN, Nilai, Negeri Sembilan, Malaysia

${ }^{3}$ All Cosmos Bio-Tech Holding Corporation, PLO650, Jalan Keluli, Pasir Gudang Industrial Estate, Johor, Malaysia

${ }^{4}$ Fisheries Research Institute, Batu Maung, Malaysia

${ }^{5}$ Humanology Sdn Bhd, Malaysia

*Corresponding Author: Chee Kong Yap, Department of Biology, Faculty of Science, Universiti Putra Malaysia, Selangor, Malaysia.

E-mail: yapckong@hotmail.com

Received: June 17, 2019; Published: July 24, 2019

DOI: $10.31080 /$ ASNH.2019.03.0376

\begin{abstract}
Samples of prawn (Penaeus merguiensis), were collected from a market in Serdang, Selangor, Peninsular Malaysia, in 2007. The prawns samples were dissected into five parts; soft tissue, carapace, periopods, pleopods and telson. The mean metal concentrations ( $\mu \mathrm{g} / \mathrm{g}$ dry weight) in the soft tissues of the prawns were 89.2 for Fe, 13.6 for $\mathrm{Cu}, 55.5$ for $\mathrm{Zn}, 0.01$ for Cd and 0.01 for Ni. For the human health risk assessment, all values of target hazard quotient for the five metals in the adults of Malaysian population were found below 1.00. This showed that there was no non-carcinogenic risk of the five metals via the consumption of $P$. merguiensis from the present study. Still, it is highly recommended that frequent monitoring of toxic chemicals besides heavy metals should be carried out for possible chemical contamination in this popular seafood in Malaysia.
\end{abstract}

Keywords: Heavy Metals; Health Risk Assessment; Penaeus merguiensis

\section{Introduction}

The prawn Penaeus merguiensis (Family: Penaeidae) were focused in the present study. They are natural dwellers of the coastal areas of Peninsular Malaysia and hold significant commercial values in the prawn farming industry since 1980s [1]. Therefore, the evaluation of human safety consumption of these prawns is of utmost importance.

Studies of heavy metals in the prawns have been reported in green tiger prawns (P. semisulcatus) from Turkey Kaya and Turkoglu [2], giant tiger prawns (P. monodon) from the Tanzanian coast $[3,4]$, in P. semisulcatus from Khuzestan province, Iran [5], in P. semisulcatus caught from southern Red Sea coast of Saudi Arabia
[6], in Chinese shrimp P. chinensis [7], in P. monodon from Langat estuary of Peninsular Malaysia [8], and P. monodon from Tuaran and Likas of near Kota Kinabalu [9].

Marine shrimp species has long been used as a bioindicators for heavy metals pollution in numerous environmental monitoring studies $[10,11]$. However, the bioaccumulation of heavy metal in these organisms is influenced affected by many biological and environmental factors.

The objectives of this study are to: 1 ) investigate the concentrations of $\mathrm{Cd}, \mathrm{Cu}, \mathrm{Fe}, \mathrm{Ni}$ and $\mathrm{Zn}$ in P. merguiensis bought from a market in Sri Serdang, Selangor and; 2) to determine the target hazard quotients of heavy metals in the prawns bought from Sri Serdang market in comparison to cited data. 


\section{Materials and Methods}

The prawn samples $P$. merguiensis were bought from a market (pasar) in Sri Serdang, Selangor, Peninsular Malaysia, on the 5 April 2007. Twenty five individual of prawns were selected and dissected into several different parts: soft tissue, carapace, front legs (periopods), hind legs (pleopods) and telson. The ranges for the total wet weights, and body lengths were 6.65-9.32 $\mathrm{g}$ and 3.80$5.44 \mathrm{~cm}$, respectively.

All collected shrimp samples were kept frozen until dissection was carried out. The frozen samples were thawed at room temperature and later on, cleaned with double-distilled water (DDW). Determination of total soft tissue dry weight were conducted by drying individual whole STs at $60^{\circ} \mathrm{C}$, for 72 hours until constant dry weight was achieved [12]. The prawn samples were placed onto aluminum foils dried at $105^{\circ} \mathrm{C}$, for 72 hours until constant dry weight was achieved [12].

The dissected dried tissues (about 0.5g each) were weighed and digested in concentrated nitric acid (AnalaR grade, BDH 69\%). Digestion were carried out by heating the nitric acid treated samples at $40^{\circ} \mathrm{C}$ for 1 hour and then raised to $140^{\circ} \mathrm{C}$ for at least 3 hours to achieve full digestion. After the digestion process was completed, the samples were topped up with DDW to $40 \mathrm{ml}$ and before filtering them with Whatman No.1 (filter speed: medium) filter papers into acid washed plastic containers. The digested samples were then sent for $\mathrm{Cd}, \mathrm{Cu}, \mathrm{Fe}, \mathrm{Ni}$, and $\mathrm{Zn}$ determination by using the atomic absorption spectrophotometer (AAS) Perkin-Elmer Model 800 .

All glassware and equipment used for this study were acid washed and procedural blanks were analyzed once for every five samples during analysis to ensure consistency in data collection. Standard solutions for all five metals were prepared and analyzed occasionally during the analysis for heavy metal recoveries. The heavy metal recoveries were being satisfactory with recoveries between $90-110 \%$. The quality of the analytical procedures used for the prawn samples were verified by using CRM for Dogfish Liver (DOLT-3, National Research Council Canada). The recoveries for the CRMs were being satisfactory between $80-120 \%$.

\section{Human health risk assessment}

The estimated daily intake is to calculate how much of prawns that be taken by an adult for one day. First, the dry weight (dw) basis was converted to wet weight ( $\mathrm{ww}$ ) by using the conversion factor (0.30) as follows:

Wet weight $(\mathrm{WW})=$ metal concentration $(\mathrm{MC}) \mathrm{X}$ conversion factor

The mean concentrations of the samples are needed for calculation of estimated daily intake of prawns. The estimated daily intake (EDI) $(\mu \mathrm{g} / \mathrm{kg} /$ day) of prawns that contain levels of $\mathrm{Cd}, \mathrm{Cu}, \mathrm{Fe}, \mathrm{Ni}$, and $\mathrm{Zn}$ were measured by using a formula:

\section{$\mathrm{EDI}=\mathrm{MC} \times \mathrm{CR} /(\mathrm{BW})$}

$\mathrm{MC}$ represents the metal concentration ( $\mu \mathrm{g} / \mathrm{g}$ wet weight) in the prawns. The body weight (BW; kg) for adults is $62 \mathrm{~kg}$ and consumption rate (CR; g/person/day) for cephalopod is $90 \mathrm{~g}$, following the report for Malaysian population [13].

The human health risk assessment of the heavy metal in the guava fruits was determined by the calculation of Target Hazard Quotient (THQ). If the THQ value is higher than 1.0, this means that the daily consumption of prawns would likely result in negative health effects during a lifetime in a human population [14]. The formula of THQ calculation was described as follow:

$\mathrm{THQ}=\mathrm{EDI} / \mathrm{RfD}$

RfD represents the oral references dose $(\mu \mathrm{g} / \mathrm{kg} /$ day $)$. The reference doses used for $\mathrm{Cd}, \mathrm{Cu}, \mathrm{Fe}, \mathrm{Ni}$, and $\mathrm{Zn}$ are 1, 40, 700, 20 and 300, respectively, provided by the USEPA's regional screening level [15].

\section{Results and Discussion}

The mean concentrations of $\mathrm{Fe}, \mathrm{Cu}, \mathrm{Zn}, \mathrm{Cd}$ and $\mathrm{Ni}$ in P. merguiensis bought from market in Sri Serdang are presented in Table 1. The order of Fe and $\mathrm{Zn}$ levels are hind legs $>$ front legs $>$ telson $>$ soft tissue $>$ carapace, while carapace $>$ front legs $>$ telson $>$ hind legs $>$ soft tissue for Cd and Ni. Pourang., et al. [16] reported the highest level of $\mathrm{Cd}(0.790 \mu \mathrm{g} / \mathrm{g}$ wet weight) was observed in exoskeleton (equivalent to carapace) of $P$. semisulcatus. The order of $\mathrm{Cu}$ levels are hind legs $>$ front legs $>$ telson $>$ carapace $>$ soft tissue. The mean metal 
concentrations ( $\mu \mathrm{g} / \mathrm{g}$ dry weight) in the soft tissues of the prawns were 89.2 for $\mathrm{Fe}, 13.6$ for $\mathrm{Cu}, 55.5$ for $\mathrm{Zn}, 0.01$ for $\mathrm{Cd}$ and 0.01 for $\mathrm{Ni}$. These metal ranges were also below the maximum permissible limits set by the Malaysian Food Regulation [17].

Table 1: Mean concentrations ( $\mu \mathrm{g} / \mathrm{g}$ dry weight) of $\mathrm{Fe}, \mathrm{Cu}, \mathrm{Zn}$, $\mathrm{Cd}$ and $\mathrm{Ni}$ in the prawn Penaeus merguiensis from a market in Sri Serdang.

\begin{tabular}{|l|c|c|c|c|c|}
\hline & Fe & Cu & Zn & Cd & Ni \\
\hline Soft tissue & 89.2 & 13.6 & 55.5 & 0.01 & 0.01 \\
\hline Carapace & 42.9 & 18.0 & 25.1 & 1.71 & 8.09 \\
\hline Front legs & 122 & 40.9 & 78.6 & 1.68 & 5.83 \\
\hline Hind legs & 138 & 122 & 78.7 & 0.88 & 2.32 \\
\hline Telson & 99.2 & 38.1 & 35.2 & 1.20 & 6.33 \\
\hline
\end{tabular}

The concentrations of $\mathrm{Cd}, \mathrm{Cu}, \mathrm{Fe}, \mathrm{Ni}$ and $\mathrm{Zn}$ of $P$. merguiensis, from the present study and cited data from the literature are presented in Table 2. Overall, the five metal levels found from Sri Serdang market were lower or within the ranges as those reported in the literature (Table 2).

The values of EDI and THQ of $\mathrm{Cd}, \mathrm{Cu}, \mathrm{Fe}, \mathrm{Ni}$ and $\mathrm{Zn}$ of P. merguiensis, from the present study and cited data from the literature, are shown in Table 3. All values of THQ for the five metals in the adults of Malaysian population were found below 1.00. This shows that there was no non-carcinogenic risk of the five metals via the consumption of $P$. merguiensis from the present study. Still, it is highly recommended that frequent monitoring of toxic chemicals besides heavy metals should be carried out for possible chemical contamination in the popular seafood in Malaysia.

Table 2: Concentrations ( $\mu \mathrm{g} / \mathrm{g}$ dry weight) of $\mathrm{Cd}, \mathrm{Cu}, \mathrm{Fe}, \mathrm{Ni}$ and $\mathrm{Zn}$ of Penaeus merguiensis, from the present study and cited data from the literature. DW= Dry weight; WW= Wet weight.

Note: The $\mu \mathrm{g} / \mathrm{g}$ dry weights were converted by using conversion factors of 0.30 , assuming the water content is $70 \%$.

1= Anandkumar., et al. [18]; 2= Mitra., et al. [19]; 3= Alam [20].

\begin{tabular}{|l|c|c|c|c|c|c|c|c|c|c|}
\hline & \multicolumn{4}{|c}{ DW } & \multicolumn{4}{c|}{ WW } \\
\hline Sampling site & $\mathrm{Ni}$ & $\mathrm{Cu}$ & $\mathrm{Zn}$ & $\mathrm{Cd}$ & $\mathrm{Fe}$ & $\mathrm{Ni}$ & $\mathrm{Cu}$ & $\mathrm{Zn}$ & $\mathrm{Cd}$ & $\mathrm{Fe}$ \\
\hline Serdang market & 0.01 & 13.55 & 55.54 & 0.01 & 89.17 & 0.003 & 4.065 & 16.7 & 0.003 & 26.751 \\
\hline Miri coast $^{1}$ & 2.3 & 80.8 & 104 & 0.1 & $\mathrm{NA}$ & 0.69 & 24.24 & 31.2 & 0.03 & NA \\
\hline Indian Sundarbans $^{2}$ (min) & $\mathrm{NA}$ & 13 & 22 & 0.00 & $\mathrm{NA}$ & $\mathrm{NA}$ & 3.9 & 6.6 & 0.0003 & NA \\
\hline Indian Sundarbans $^{2}$ (max) & $\mathrm{NA}$ & 42 & 95 & 3.90 & $\mathrm{NA}$ & $\mathrm{NA}$ & 12.6 & 28.5 & 1.17 & NA \\
\hline Kapar $^{3}$ & $\mathrm{NA}$ & 21.6 & 76.4 & 0.17 & $\mathrm{NA}$ & $\mathrm{NA}$ & 6.48 & 22.92 & 0.051 & NA \\
\hline
\end{tabular}

Table 3: Values of estimated daily intake (EDI) and target hazard quotient (THQ) of Cd, Cu, Fe, Ni and Zn of Penaeus merguiensis, from the present study and cited data from the literature.

Note: 1= Anandkumar., et al. [18]; 2= Mitra., et al. [19]; 3= Alam [20].

\begin{tabular}{|l|c|c|c|c|c|c|c|c|c|c|}
\hline & \multicolumn{4}{|c|}{ EDI } & \multicolumn{4}{c|}{ THQ } \\
\hline Sampling site & $\mathrm{Ni}$ & $\mathrm{Cu}$ & $\mathrm{Zn}$ & $\mathrm{Cd}$ & $\mathrm{Fe}$ & $\mathrm{Ni}$ & $\mathrm{Cu}$ & Zn & $\mathrm{Cd}$ & Fe \\
\hline Serdang market & 0.004 & 5.90 & 24.1 & 0.004 & 38.8 & 0.0002 & 0.148 & 0.081 & 0.004 & 0.055 \\
\hline Miri coast $^{1}$ & 1.002 & 35.18 & 45.3 & 0.044 & $\mathrm{NA}$ & 0.050 & 0.880 & 0.151 & 0.044 & NA \\
\hline Indian Sundarbans $^{2}$ (min) & $\mathrm{NA}$ & 5.661 & 9.58 & 0.0004 & $\mathrm{NA}$ & $\mathrm{NA}$ & 0.142 & 0.032 & 0.000 & NA \\
\hline Indian Sundarbans $^{2}$ (max) & $\mathrm{NA}$ & 18.29 & 41.4 & 1.70 & $\mathrm{NA}$ & $\mathrm{NA}$ & 0.457 & 0.138 & 1.698 & NA \\
\hline Kapar $^{3}$ & $\mathrm{NA}$ & 9.406 & 33.3 & 0.074 & $\mathrm{NA}$ & $\mathrm{NA}$ & 0.235 & 0.111 & 0.074 & NA \\
\hline
\end{tabular}


Mokhtar., et al. [8] reported that the levels of $\mathrm{Cd}, \mathrm{Ni}, \mathrm{Cu}, \mathrm{Fe}$, and $\mathrm{Zn}$ in P. monodon were found to be lower than the recommended maximum level allowed in food, thus indicating that $P$. monodon from Bandar and Jugra aquaculture ponds were save for human consumption. Based on samples collected from Iskenderun Bay, Yilmaz and Yilmaz [21] reported that the heavy metal concentrations, except for $\mathrm{Cu}$, in male and female P. semisulcatus's muscle were below the admissible limits. This metal elevation was assumed to be contributed by industrial pollution.

According to Frenet and Alliot [22], the role played by $\mathrm{Cu}$ in the production haemocyanin (an essential respiratory protein) could result in high $\mathrm{Cu}$ levels in the prawns, while $\mathrm{Zn}$ plays an important role in a variety of an essential respiratory protein and enzymatic processes.

\section{Conclusions}

From the data obtained in this study, prawns collected from a market in Sri Serdang are safe for human consumption. However, regular monitoring of heavy metal non-carcinogenic risks in this prawn and other species should be made to check for the possible human health risks.

\section{Bibliography}

1. Chong VC and Sasekumar A. "Food and feeding habits of the white prawn Penaeus merguiensis". Marine Ecology Progress Series 5 (1982): 185-191.

2. Kaya G and Turkoglu S. "Bioaccumulation of heavy metals in various tissues of some fish species and green tiger shrimp (Penaeus semisulcatus) from İskenderun Bay, Turkey, and risk assessment for human health". Biological Trace Element Research 180 (2017): 314-326.

3. Rumisha C., et al. "Trace metals in the giant tiger prawn Penaeus monodon and mangrove sediments of the Tanzania coast: Is there a risk to marine fauna and public health?" Ecotoxicology and Environmental Safety 132 (2016): 77-86.

4. Rumisha C., et al. "Bioaccumulation and public health implications of trace metals in edible tissues of the crustaceans Scylla serrata and Penaeus monodon from the Tanzanian coast". Environmental Monitoring and Assessment 189 (2017): 529.

5. Sharifi R., et al. "Essential heavy metal concentrations (Zn, Fe, $\mathrm{Cu}, \mathrm{Mg}$ and $\mathrm{Mn}$ ) in muscle tissue of green tiger shrimp, Penaeus semisulcatus, with different size classes". Journal of Animal and Plant Sciences 27 (2017): 1402-1407.
6. El Gendy., et al. "Heavy metal concentrations in tissues of the shrimp Penaeus semisulcatus (De Haan, 1844) from Jazan, southern Red Sea coast of Saudi Arabia”. Pakistan Journal of Zoology 47 (2015): 671-677.

7. Xie B., et al. "Effects of conventional versus organic production systems on amino acid profiles and heavy metal concentrations in the Chinese shrimp Penaeus chinensis". Fisheries science 77 (2011): 839-845.

8. Mokhtar MB., et al. "Assessment level of heavy metals in Penaeus monodon and Oreochromis spp. in selected aquaculture ponds of high densities development area". European Journal of Scientific Research 30 (2009): 348-360.

9. Hashmi MI., et al. "Heavy metal concentrations in water and tiger prawn (Penaeus monodon) from grow-out farms in Sabah, North Borneo". Food Chemistry 79 (2002): 151-156.

10. Darmono D and Denton GRW. "Heavy metal concentrations in the banana prawn, Panaeus merguiensis, and leader prawn, P. monodon, in the Townsville Region of Australia". Bulletin of Environmental Contamination and Toxicology 44 (1990): 479486.

11. Dallinger R. "Invertebrate organisms as biological indicators of heavy metal pollution". Applications Human Biotechnology 48 (1994): 27-31.

12. Mo C and Neilson B. "Standardization of oyster dry weight measurements". Water Research 28 (1994): 243-246.

13. Nurul Izzah A., et al. "Fish consumption pattern among adults of different ethnics in Peninsular Malaysia". Food and Nutrition Research 60 (2016): 32697.

14. Bogdanovic T., et al. "As, $\mathrm{Cd}, \mathrm{Hg}$ and $\mathrm{Pb}$ in four edible shellfish species from breeding and harvesting areas along the eastern Adriatic Coast, Croatia”. Food Chemistry 146 (2014): 197-203.

15. USEPA (US Environmental Protection Agency). Human health risk assessment. Regional screening level (RSL) - summary table (2015).

16. Pourang N., et al. "Distribution of heavy metals in Penaeus semisulcatus from Persian Gulf and possible role of metallothionein in their redistribution during storage". Environmental Monitoring and Assessment 100 (2005): 71-88.

17. Malaysian Food Regulation. "Malaysian law on food and drugs". Malaysian Law Publishers (1985): 1-50. 
18. Anandkumar A., et al. "Trace metal dynamics and risk assessment in the commercially important marine shrimp species collected from the Miri coast, Sarawak, East Malaysia". Regional Studies in Marine Science 16 (2017): 79-88.

19. Mitra A., et al. "Analysis of trace metals in commercially important crustaceans collected from UNESCO Protected World Heritage Site of Indian Sundarbans". Turkish Journal of Fisheries and Aquatic Sciences 12 (2012): 53-66.

20. Alam K. "Investigation of Po-210 and heavy metal concentration in seafood due to coal burning - Case study in Malaysia" (2016).

21. Yilmaz AB and Yilmaz L. "Influences of sex and seasons on levels of heavy metals in tissues of green tiger shrimp (Penaeus semisulcatus de Hann, 1844)". Food Chemistry 101 (2007): 1664-1669.

22. Frenet $\mathrm{M}$ and A Alliot. "Comparative bioaccumulation of metals in Palaemonetes varians in polluted and non-polluted environments". Marine Environmental Research 17 (1985): 19-44.

Volume 3 Issue 8 August 2019

(C) All rights are reserved by Chee Kong Yap., et al. 